\title{
Monitoring of parasitic cysts in the brains of a flock of sheep in Egypt
}

\author{
Monitoramento de cistos parasitários no cérebro de um rebanho de ovinos no Egito \\ Shehata Anwar ${ }^{1,3}$; Emad Mahdy ${ }^{1}$; Khalid Ali El-Nesr ${ }^{1}$; Khaled Mohamed El-Dakhly²,3; \\ Adel Shalaby ${ }^{1}$; Tokuma Yanai ${ }^{3 *}$ \\ ${ }^{1}$ Department of Pathology, Faculty of Veterinary Medicine, Beni-Suef University - BU, Beni-Suef 62511, Egypt \\ ${ }^{2}$ Department of Parasitology, Faculty of Veterinary Medicine, Beni-Suef University - BU, Beni-Suef 62511, Egypt \\ ${ }^{3}$ Department of Veterinary Pathology, Faculty of Applied Biological Science, Gifu University - GU, 1-1 Yanagido, Gifu 501-1193, Japan
}

Received December 10, 2012

Accepted May 7, 2013

\begin{abstract}
Cerebral parasitic cysts constitute a major problem for livestock. Among these, coenurosis and toxoplasmosis are predominant. Here, a total number of 60 sheep obtained from a private farm in Suez province, Egypt, were examined postmortem to detect visible parasitic cysts, and microscopically to detect small-sized entities. Necropsy revealed bladder-like cysts measuring $0.5-6.5 \mathrm{~cm}$ in diameter that were filled with a translucent fluid containing a large number of protoscolices. Accordingly, the cysts were identified as the metacestode Coenurus cerebralis. Among the sheep examined, 11 animals (7 males and 4 females) (18.3\%) were infected. Most of the cysts were located in the cerebral hemispheres, with numbers ranging from one to three per infected animal. The effect of the presence of cysts in the brain tissue was evaluated. Histopathologically, pseudocysts of the apicomplexan Toxoplasma gondii were found in two animals with no detectable inflammatory cell reactions. In conclusion, coenurosis and toxoplasmosis are serious parasitic problems that play a significant role in sheep management in Egypt, as a result of close contact between livestock and dogs and cats, which play a critical role in the life cycle of these parasites.
\end{abstract}

Keywords: Coenurus cerebralis, Toxoplasma gondii, sheep.

\section{Resumo}

Cistos cerebrais parasitários constituem um grande problema para o gado. Entre estes, coenurosis e toxoplasmose são predominantes. Aqui, um número total de 60 ovelhas obtidas em uma fazenda particular na província Suez, Egito, foram examinadas post-mortem para a detecção de cistos parasitários visíveis e microscopicamente para detectar cistos de pequenas dimensóes. A necropsia revelou cistos medindo entre 0,5-6,5 cm de diâmetro, preenchidos com um fluido transparente, contendo um grande número de protoscolices. Por conseguinte, os cistos foram identificados como o metacestóide Coenurus cerebralis. Entre as ovelhas examinadas, 11 animais (7 machos e 4 fêmeas) (18,3\%) estavam infectados. A maior parte dos cistos estavam localizados nos hemisférios cerebrais, com números variando de um a três em ovinos infectados. O efeito da presença de cistos no tecido do cérebro foi avaliado. Histopatologicamente, pseudocistos de Toxoplasma gondii foram encontrados em dois animais sem reaçóes inflamatórias detectáveis. Em conclusão, coenurosis e toxoplasmose são graves problemas parasitários que desempenham um papel significativo no manejo de ovelhas no Egito, como resultado do contacto íntimo dos animais com os cáes e gatos, que desempenham um papel crítico no ciclo de vida desses parasitas.

Palavras-chave: Coenurus cerebralis, Toxoplasma gondii, ovinos.

\section{Introduction}

Cerebral coenurosis, or alternatively central nervous system (CNS) coenurosis, is an infection caused by the metacestode Coenurus cerebralis, of Taenia multiceps Leske, 1780. The adult

\footnotetext{
*Corresponding author: Tokuma Yanai

Department of Veterinary Pathology, Faculty of Applied Biological Science,

Gifu University, 1-1 Yanagido, Gifu, 501-1193, Japan

e-mail: yanai@gifu-u.ac.jp
}

worm inhabits the small intestine of domestic and wild canids, and dogs are the most frequent definitive host. The metacestodes (larval stages) develop in the brain and spinal cord of sheep, goats and other ungulates that have ingested eggs or gravid segments of T. multiceps, thereby inducing so-called cerebral coenurosis (BATISTA et al., 2010).

Coenurus cerebralis poses serious problems for sheep and goat production. It has worldwide distribution but is more 
common in the developing countries of Africa and Asia, with prevalences ranging from 1.3 to 9.8\% (ACHENEF et al., 1999; ABO-SHEHADA et al., 2002; SHARMA; CHAUHAN, 2006; WELCHMAN; BEKR-OCHIR, 2006; GICIK et al., 2007; SCALA et al., 2007; NOURANI; KHEIRABADI, 2009; OGE et al., 2012), where sheep and goat rearing is a common source of income.

Coenurosis is a fatal disease, and death occurs as a result of encephalitis, on average 30 days post-infection (CHRISTODOULOPOULOS, 2007; BATISTA et al., 2010). In the acute phase, immature parasites migrate to the CNS, and the clinical signs together with the severity of the condition are closely related to the number of viable eggs ingested by the sheep, with intense inflammatory cell reactions occurring as a result of the parasite localization (SCALA et al., 2007; PALTRINIERI et al., 2010). If the metacestode is overcome by the host immune response, clinical recovery takes place and only small caseous lesions are found during necropsy (EDWARDS; HERBERT, 1982). The clinical signs of ovine coenurosis may be confused with other diseases such as listeriosis, polioencephalomalacia or brain abscess (EDWARDS; HERBERT, 1982). Therefore, the diagnosis is based on epidemiological and clinical evaluations as well as necropsy findings and anatomohistopathological investigation (RISSI et al., 2008). Chronic cases known as "gid" or "sturdy" appear in older sheep as a result of cyst development. Infected sheep usually remain isolated from the flock and show loss of reactivity to external stimuli. As the cyst increases in size, the clinical signs become more evident including depression, ataxia, circular movements, blindness and head deviation (BUSSELL et al., 1997; ACHENEF et al., 1999). Most infected animals die as a result of starvation within a few weeks (HERBERT et al., 1984). In chronic cases, brain tissue displacement and atrophy occur due to the pressure exerted by mature $C$. cerebralis cysts, with varying degrees of necrosis and congestion (ACHENEF et al., 1999).

Small ruminants like sheep and goats are intermediate hosts of Toxoplasma gondii (DUBEY, 2009, 2010). Meat from these animals is regarded as an important source of nutrition for humans. T. gondii infection tends to be especially high in countries and regions that depend on mutton and goat meat (KIJLSTRA; JONGERT, 2008). Sheep are usually infected with $T$. gondii, which may cause early embryonic death, abortion, stillbirth and neonatal death. T. gondii in sheep is a source of infection for humans and carnivorous animals (BUXTON, 1998; ASGARI et al., 2011; TZANIDAKIS et al., 2012). As a result of the significant consumption of products originating from small ruminants in the Mediterranean area, there is a high risk of human infection. Consequently, there is an urgent need to elucidate the factors that cause it to spread, as well as the risk factors for this zoonotic disease in small ruminants.

The purposes of this investigation were to evaluate the parasitic cysts present in the brain tissues of slaughtered sheep obtained from a private farm in Suez province, Egypt; to highlight their prevalence and distribution pattern; and to determine the pathological alterations in brain tissues that occur as a result of the presence of these cysts.

\section{Materials and Methods}

\section{Animals and study area}

An extensively raised herd of sheep belonging to a private farm in Suez province (coordinates: 29 $9^{\circ} 59^{\prime} \mathrm{N} 32^{\circ} 33^{\prime} \mathrm{E}$ ), Egypt, was examined at the time of slaughtering in order to detect parasitic cysts in the brain, during the period from December 2008 to February 2010. Osimi, Saidi and Rahmani sheep breeds were examined; of these, Osimi was the most prevalent breed. The animals were kept under veterinary care to detect abnormal clinical manifestations. Data concerning general conditions and mortalities were recorded. Consideration was given to the vaccination program of the farm against clostridial diseases, as well as viral diseases such as foot and mouth disease, pox and Rift Valley fever. Palpation and close inspection of the entire body surface were performed in order to detect intermuscular and subcutaneous cysts. A total of 60 sheep, aged from 3 months to 3.5 years, were necropsied and their brains were examined grossly for large parasitic cysts. Histopathological examination was conducted to reveal small-sized cysts.

\section{Necropsy}

Necropsy was done at the time of slaughtering. The animals were subjected to a full postmortem examination. The head was detached by severing the atlanto-occipital joint. Horns, ears and the skin of the caudal half of the skull were removed. The roof of the cranial vault was cut using an electrical saw, the meninges were pushed aside and the brain was removed by turning the skull upside down. The cranial nerves were severed by blunt dissection (SCALA et al., 2007; DESOUKY et al., 2011). The whole brain was carefully removed. A preliminary examination for cysts and gross pathological lesions was carried out. The whole brain was fixed in $20 \%$ neutral buffered formalin. Coronal sections were sliced through the longitudinal axis of the brain at $5 \mathrm{~mm}$ intervals, in accordance with the method described by Leontides et al. (2000), in order to ensure that a wide range of neuroanatomical structures were sampled, and in order to detect the presence of cysts and other similar lesions. The dimensions of cysts and their locations were recorded and photographed.

\section{Parasitological examination}

The gross and morphological features of the cysts were identified and evaluated. The cysts were seen to be large white structures filled with translucent fluid containing numerous spherules (protoscolices) attached to the wall, and the scolex had a double ring of rostellar hooks (AVCIOGLU et al., 2012). The viability of each metacestode was assessed by means of microscopic examination following incubation at $37^{\circ} \mathrm{C}$ for 5 minutes to check the motility and evagination of the protoscolices.

\section{Histopathology}

Brain tissue specimens were fixed in 20\% formol saline. Samples were processed routinely by means of paraffin embedding. Sections 
of thickness $5 \mu \mathrm{m}$ were stained with hematoxylin and eosin (HE) (BANCROFT; GAMBLE, 2008) and Giemsa (NAYEL et al., 2012) for microscopic examination.

\section{Results}

The clinical histories of the animals examined revealed that varying degrees of nervous signs appeared in 35\% (21/60) of the sheep in the form of dullness, circling, torticollis, loss of appetite, frequent bleating, impaired vision, occasional unilateral partial blindness, tilting of the head either right or left, head pressing, inertia, incoordination, irregular gait, failure to hold the head straight, feet stamping and recumbency, ending with exhaustion and death.

Necropsy revealed brain lesions in the subcortex of the cerebral hemisphere and cerebellum, consisting of bladder-like cysts measuring about $5 \mathrm{~cm}$ in diameter, filled with a translucent fluid containing a large number of floating white spherules (protoscolices) of Coenurus cerebralis. In addition, lesions in the brain tissue were histopathologically described. Among the 60 sheep examined, Coenurus cerebralis cysts were found in the brains of 11 heads (18.3\%). The cerebrum was the part most often affected, either in the right cerebral hemisphere ( 4 animals) or the left hemisphere (6 animals), followed by the cerebellum (one case was infected on the right side) (Table 1 ).

The number of cysts in the infected animals varied; four animals had one cyst each, five were infected with two cysts, and two had three cysts in the brain tissue (Table 2). It is noteworthy that the $C$. cerebralis infection rate was not significantly different between male sheep (7) and female sheep (4) (Table 3). On slaughtering or immediately after death, the age of the animals was determined based on dentition. The diameters of the cysts revealed ranged from 0.5 to $6.5 \mathrm{~cm}$ (Figure 1a). A bladder-like cyst filled with a translucent fluid was seen, with large numbers of white spherules (protoscolices), floating in the fluid inside the cystic cavity (Figure 1b). Smaller cystic formations (Figures 1c, d) communicating with the large ones were also observed.

Cyst formation was found to comprise almost the entire caudal hemisphere, where the brain tissue was atrophied, with

Table 1. Localization of Coenurus cerebralis cysts in different parts of infected brain tissues.

\begin{tabular}{lc}
\hline \multicolumn{1}{c}{ Location in the brain tissue } & $\begin{array}{c}\text { Number of } \boldsymbol{C} . \\
\text { cerebralis-infected sheep }\end{array}$ \\
\hline Right side of the cerebellum & 1 \\
Right cerebral hemisphere & 4 \\
Left cerebral hemisphere & 6 \\
\hline
\end{tabular}

Table 2. Number of Coenurus cerebralis cysts recovered from the slaughtered sheep.

\begin{tabular}{ccc}
\hline Total number of cysts & Number of cysts & Number of sheep \\
\hline 4 & 1 & 4 \\
10 & 2 & 5 \\
6 & 3 & 2 \\
$20^{*}$ & $6^{*}$ & $11^{*}$ \\
\hline
\end{tabular}

*Total number of cysts recovered. the inner surface presenting yellowish patches. In extending towards the lateral ventricle, cyst formation was found to cause internal hydrocephalus (Figure 2a). As the cyst grew, it replaced a large portion of the cerebral parenchyma in the right and left hemispheres. After removal of the cyst and its capsule, a cavity with an irregular wall could be seen (Figure 2b). Large cysts sometimes led to rupturing of the septum lucidum (Figure 2c) and, when the condition was aggressive, collapse and compression of the brain tissue occurred (Figure 2d).

Microscopically, C. cerebralis cysts were characterized by a thin-walled eosinophilic vesicle in which multiple evaginated spherical acoelomate scolices were observed (Figure 3a). The cyst wall was surrounded by successive evaginated layers that exhibited internal necrosis and mineralization. Distinct areas of necrosis surrounded with epithelioid cells and multinucleated giant cells were detected. These lesions were accompanied by perivascular cuffing and congestion of blood vessels (Figure 3b). The neighboring area showed perivascular congestion with lymphocytic-histiocyticplasmacytic infiltrates, and the adjacent cerebral parenchyma was compressed and atrophied. Brain tissues of animals that had suffered from nervous manifestations as a result of parasitic cysts exhibited a variety of pathological lesions that were visible grossly, microscopically, or both. In some instances, microscopic lesions were present despite the absence of clinical signs.

The present investigation revealed that two heads suffered from toxoplasmosis. Grossly, there were no detectable lesions. Microscopically, a Toxoplasma gondii cyst was found within the molecular layer of the cerebellar cortex in the first case, and within the thalamus in the other case. Within the parenchyma, the pseudocyst had many banana-shaped multiplying forms (bradyzoites). No inflammatory cell reactions could be detected in the surrounding areas. The cyst could be clearly observed using either HE (Figure 4a) or Giemsa staining (Figure 4b).

\section{Discussion}

Coenurosis is common in sheep worldwide (VERONESI et al., 2008; VARCASIA et al., 2009). The preferred site for Coenurus cysts in most cases is the central nervous system (SCHUSTER et al., 2010). The clinical signs of $C$. cerebralis infection vary depending upon the size and location of the cysts within the brain. Animals with such cysts frequently tilt their heads towards the side of the cyst and/or circle to that direction (SHARMA; CHAUHAN,

Table 3. Coenurosis in slaughtered infected sheep in relation to age and sex.

\begin{tabular}{ccc}
\hline Number of animals & Sex & Age \\
\hline 2 & Male & $<1$ year \\
1 & Female & \\
3 & Male & $1-2$ years \\
2 & Female & \\
1 & Male & $2-3$ years \\
1 & Female & \\
1 & Male & $>3$ years \\
0 & Female & \\
\hline
\end{tabular}



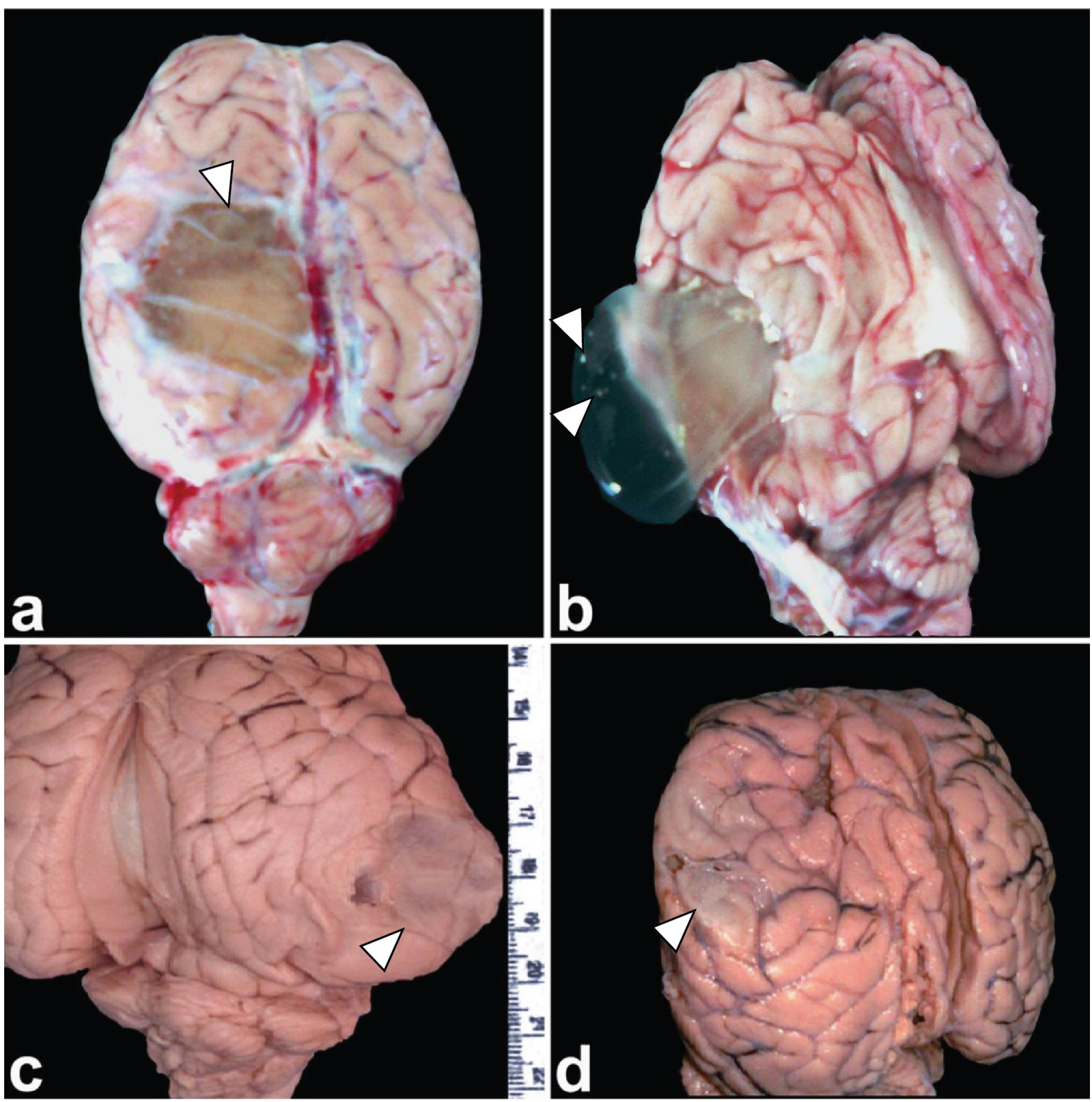

Figure 1. a) The whole brain of an infected sheep, containing a mature Coenurus cerebralis cyst in the left cerebral hemisphere; b) A large-sized bladder-like fully developed C. cerebralis cyst of about $5 \mathrm{~cm}$ in diameter, containing translucent fluid, located in the right cerebral hemisphere. Note the characteristic whitish protoscolices (arrowheads) originating from the inner germinal wall of the cyst; c) A cyst in the occipital lobe of the right cerebral hemisphere; d) A small-sized cyst in the left parietal lobe of the cerebrum.

2006; OZKAN et al., 2011). The present study revealed that the prevalence of coenurosis in slaughtered sheep was $18.3 \%$, with multiple-sized cysts. These data are consistent with those obtained by Tavassoli et al. (2011), who found that $18.65 \%$ of their sheep were infected with $C$. cerebralis cysts. Among these infected sheep, the infection rate varied significantly $(P<0.05)$, such that $42.02 \%$ of those aged $0.5-2$ years were infected, $22.50 \%$ aged $2-4$ years and $8.92 \%$ aged over 4 years. Moreover, the prevalence ranged from 1.3 to $36.8 \%$ in Turkey (USLU; GÜÇLÜ, 2007). This correlation could be due to the similarity in sheep rearing behavior and management, as well as the climatic conditions in Egypt and Iran.
Furthermore, in the present investigation, most of the cysts recovered from the slaughtered sheep were located in the right and left cerebral hemispheres, with fewest located in the cerebellum. This is completely consistent with the findings obtained by Nourani and Kheirabadi (2009), who reported that 96\% of the CNS $C$. cerebralis cysts were located in the two cerebral hemispheres and 4\% in the cerebellum. However, Edwards and Herbert (1982) stated that most of the cysts were found in the occipital area, in Welsh, Mountain, Suffolk and Dorset sheep. These discrepancies could be attributable either to the genetic variability of $T$. multiceps or to anatomical variations between the breeds of sheep. The size and location of the Coenurus cysts 

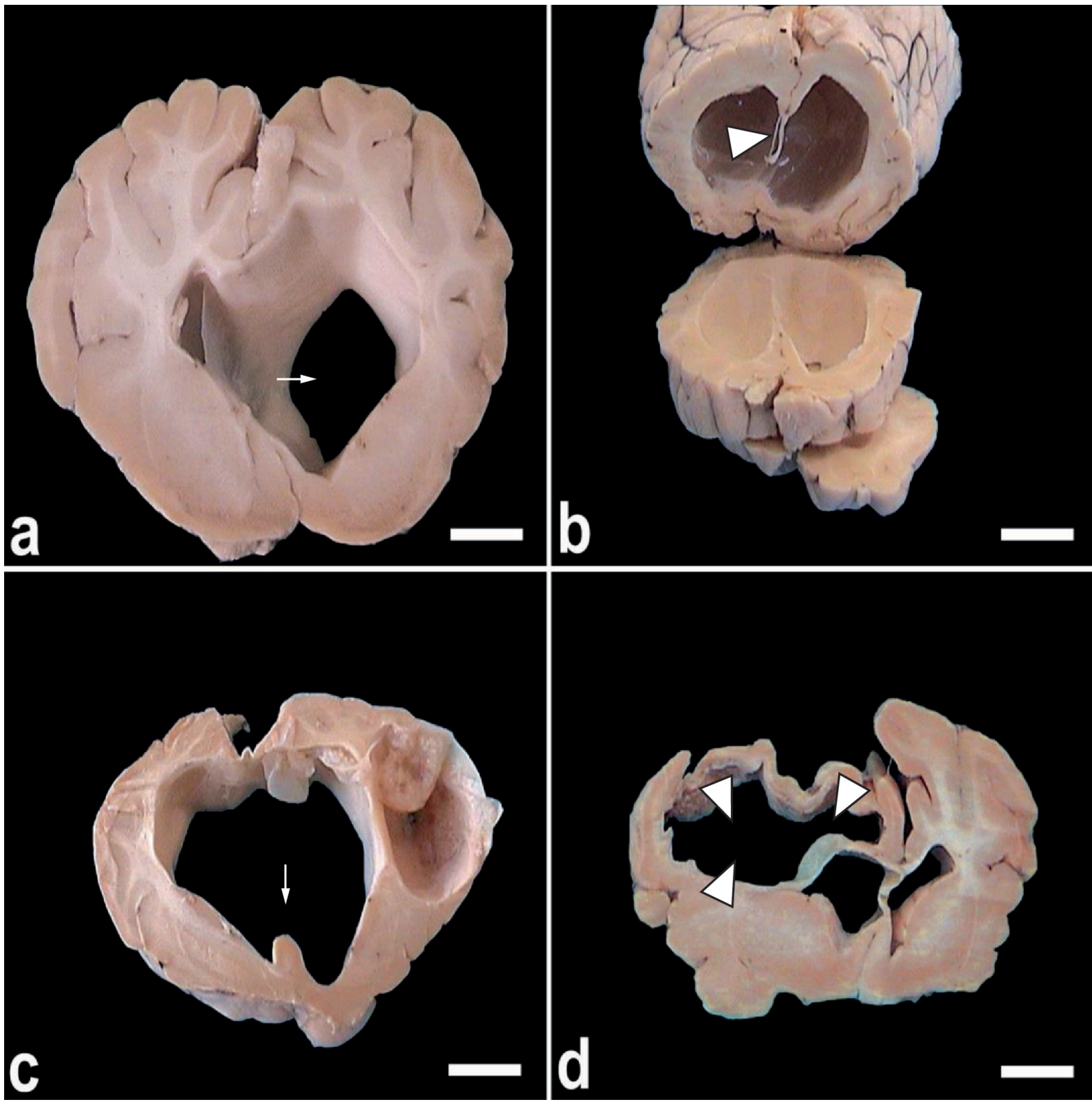

Figure 2. a) A coronal section in the brain tissue of $C$. cerebralis-infected sheep showing hydrocephalus with dilatation of the right lateral ventricle (arrow) as a result of cyst formation; b) Extensive destruction of the septum lucidum (ar head) due to cyst pressure, causing hydrocephalus; c) Rupture of the septum lucidum (septum is indicated by arrow); d) Compression of the brain tissue associated with extensive areas of malacia (arrowheads) in the right cerebral hemisphere $($ bar $=1 \mathrm{~cm}$ ).

appear to be important in the pathogenesis of the disease. The cysts recovered in the current study ranged from 0.5 to $6.5 \mathrm{~cm}$ in diameter. Similar dimensions were obtained by Güçlü et al. (2006) in Turkey. Cyst compression could lead not only to more cavitations in the cranium, but also to perforation and atrophy of the cranial bones (MANUNTA et al., 2012). Histopathologically, the cerebral coenurosis reported in this investigation was associated with formation of large and small cysts. Cyst formation was observed to comprise almost the entire caudal hemisphere where the brain tissue was atrophied, and it had an inner surface of yellowish-colored patches. In extending towards the lateral ventricle, cyst formation was found to cause internal hydrocephalus. The cysts consisted of a thin walled eosinophilic vesicle in which multiple evaginated protoscolices were floating. The cyst wall was surrounded by successive layers consisting of an internal necrotic and mineralized band, a layer of epithelioid cells with abundant numbers of multinucleated giant cells and an external fibrovascular capsule with perivascular lymphocytic-histiocytic-plasmacytic infiltrates. The adjacent white and gray matter was compressed. Similar results were obtained by Summers et al. (1995), Sharma and Chauhan (2006), Gül et al. (2007) and Rissi et al. (2008).

Surprisingly, Desouky et al. (2011) recorded a 100\% infection rate for ovine coenurosis in Egypt. This exceptionally high percentage might be related to the fact that infected heads and offal are frequently 


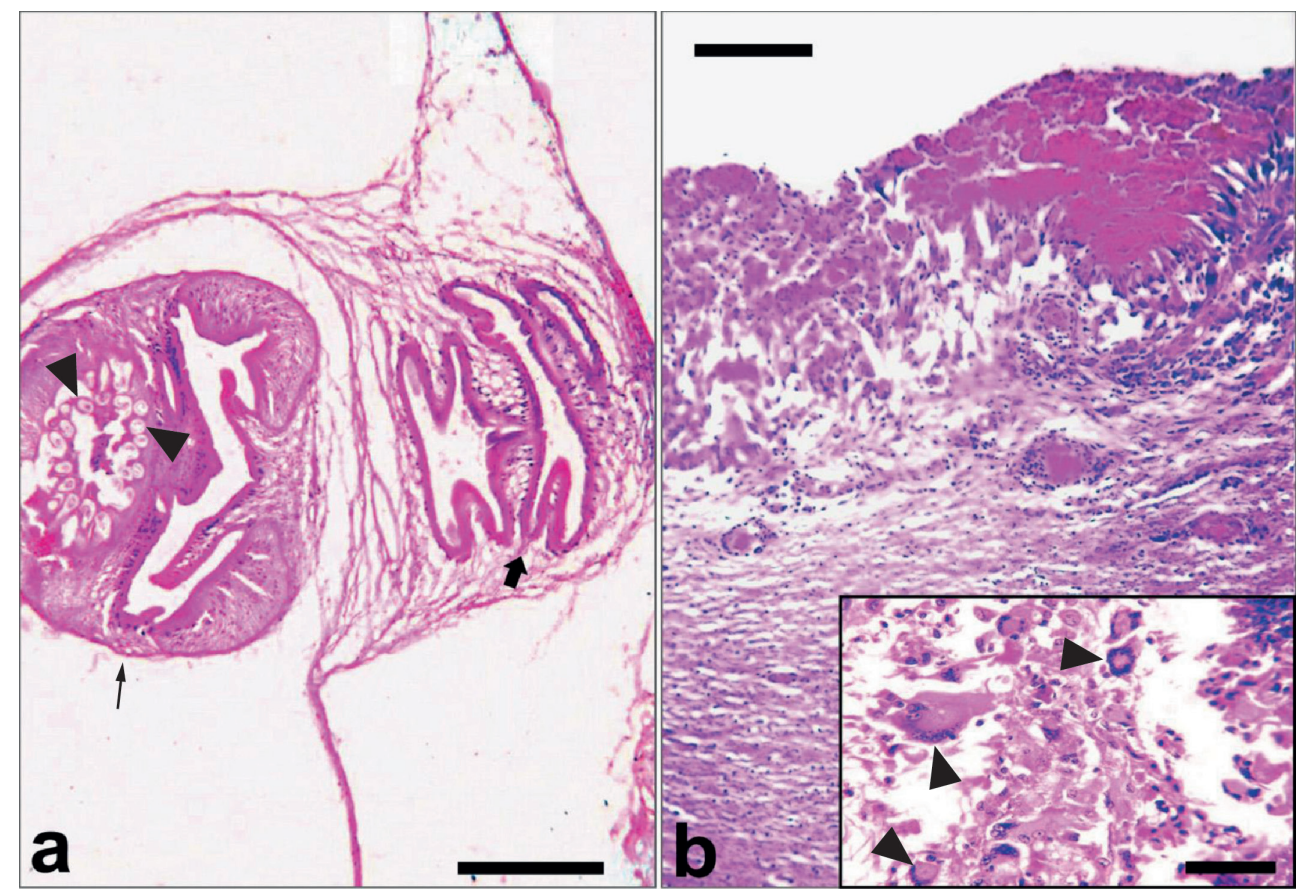

Figure 3. a) Scolex of $C$. cerebralis (arrow) showing characteristically arranged hooks (arrowheads). Note an immature scolex at the right side (bold arrow) (bar $=50 \mu \mathrm{m})$; b) Cyst wall is surrounded by a layer of necrosis (encephalomalacia) followed by aggregations of congested cerebral blood vessels, perivascular cuffing, epithelioid cells and abundant giant cells (pyogenic membrane). The adjacent cerebral parenchyma is compressed and atrophied $(\mathrm{bar}=100 \mu \mathrm{m})$. Inset: Large number of magnified well-developed giant cells $(\operatorname{arrowheads})(\mathrm{bar}=50 \mu \mathrm{m})$.

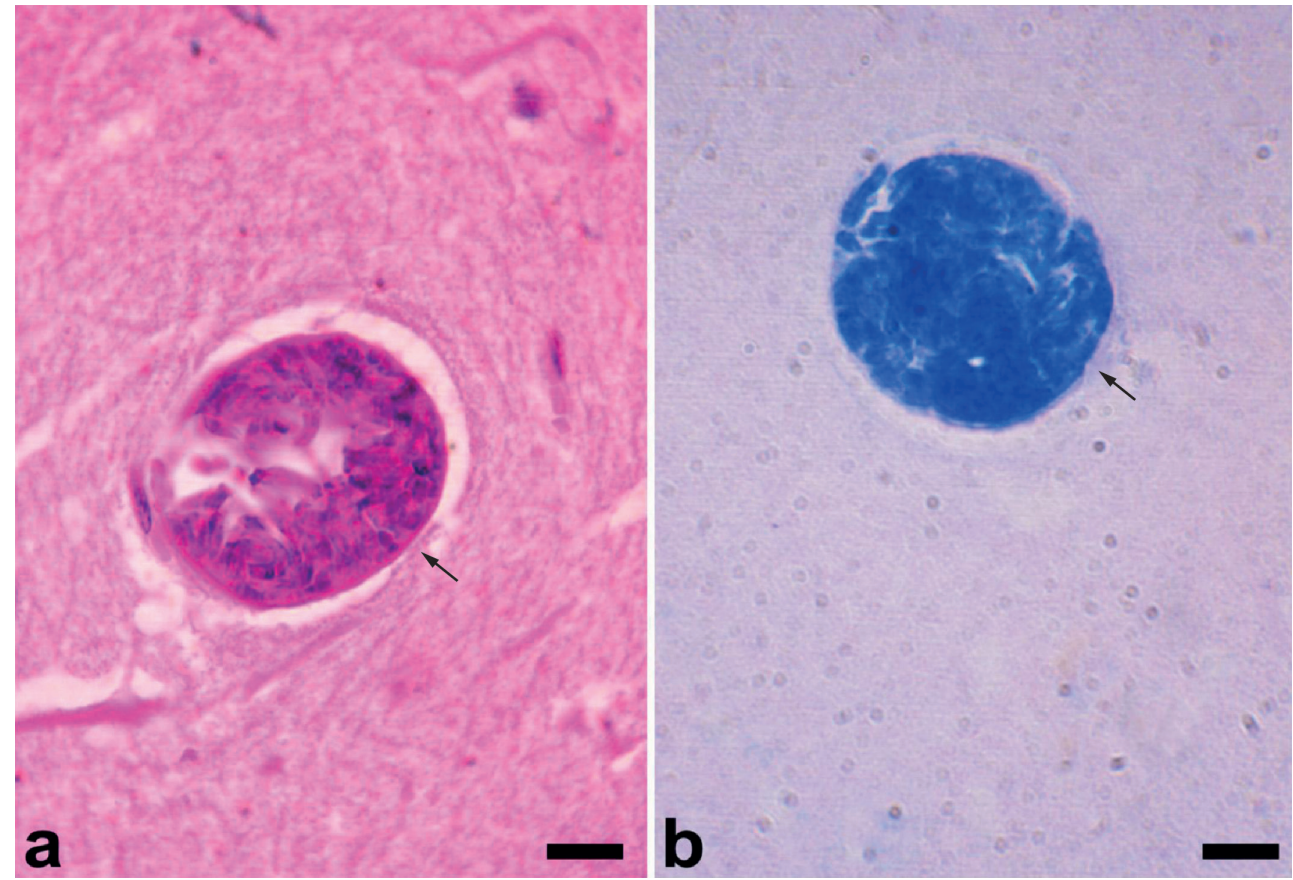

Figure 4. Toxoplasma gondii tissue cysts revealed from brain tissue of sheep (arrows). a) HE staining; b) Giemsa staining (bar = $10 \mu \mathrm{m}$ ).

offered to stray dogs during slaughtering of sheep. This creates a very high level of year-round environmental contamination by infective T. multiceps eggs disseminated through the feces of infected stray dogs. Moreover, large numbers of protoscolices per cyst might provide a continuous and abundant source of the adult cestodes in the small intestines of definitive hosts. Also, the presence of lesions at various anatomical locations and the presence of numerous cysts at different developmental stages might be the cause of the variety of signs, which means that a differential diagnosis is required, especially in the case of elderly sheep.

On the other hand, veterinarians need to be alert for lowergrade infections. These may be difficult to detect, given that in 
less developed countries, elderly sheep are illegally slaughtered in situations in which the first nervous signs appear. Owners tend to do this in order to maintain the carcass yield by avoiding the damage caused by worsening of the infection. In such situations, strict and decisive governmental measures need to be taken. Although clinical signs caused by $C$. cerebralis have been reported among sheep and goats as well as in cattle, it has been noted that some animals seemed to be healthy and were diagnosed only after death, because of absence of clinical signs while alive (SHARMA; CHAUHAN, 2006; GÜL et al., 2007).

Cats and wild felids are crucial to persistence of Toxoplasma gondii in livestock such as grazing animals, because they act as the main source of the infective oocysts that contaminate the environment (ELMORE et al., 2010). High humidity and temperate conditions favor survival of these oocysts. T. gondii tissue cysts have great affinity for neural (CNS) and muscle tissues (TENTER, 2009).

Edible tissues of sheep and goats seem to be the main sources of Toxoplasma infection among humans worldwide. High standards of hygiene in sheep breeding and management, educational programs for environmental health workers and standardization of meat handling and preparation are required in order to prevent zoonotic infection. T. gondii infection in small ruminants is not only important in terms of zoonotic issues, but also because it serves as an important cause of ovine and caprine abortion (BUXTON, 1998; INNES et al., 2009).

Microscopically, the most notable feature of toxoplasmosis was the complete absence of inflammatory cells associated with the tissue cysts. However, non-suppurative encephalitis was the main manifestation of toxoplasmosis in the brain (DUBEY; BEATTIE, 1988; ESCAJADILLO; FRENKEL, 1991).

Based on our understanding of ovine toxoplasmosis, farmers should be advised that the principal risk of infection is contamination of the environment with Toxoplasma oocysts derived from the feces of cats. In summary, effective control measures need to be implemented in order to prevent illegal slaughtering, especially of elderly and diseased sheep, and to prevent contact between livestock and canids and felids. Furthermore, hygienic disposal of dead carcasses is crucial in terms of preventive measures.

\section{Acknowledgements}

The authors sincerely thank the director and staff members of the farm for providing the slaughtered animals.

\section{References}

Abo-Shehada MN, Jebreen E, Arab B, Mukbel R, Torgerson PR. Prevalence of Taenia multiceps in sheep in northern Jordan. Prev Vet Med 2002; 55(3): 201-207. http://dx.doi.org/10.1016/S01675877(02)00056-9

Achenef M, Markos T, Feseha G, Hibret A, Tembely S. Coenurus cerebralis infection in Ethiopian highland sheep: incidence and observations on pathogenesis and clinical signs. Trop Anim Health Prod 1999; 31(1): 15-24. PMid:10399813. http://dx.doi.org/10.1023/A:1005125316275
Asgari Q, Sarnevesht J, Kalantari M, Sadat SJA, Motazedian MH, Sarkari B. Molecular survey of Toxoplasma infection in sheep and goat from Fars province, Southern Iran. Trop Anim Health Prod 2011; 43(2): 389-392. PMid:20936348. http://dx.doi.org/10.1007/s11250-010-9704-1

Avcioglu H, Terim Kapakin KA, Yildirim A. Clinical, morphological and histopathological features of bovine coenurosis: case reports. Revue Méd Vét 2012; 163(6): 295-298.

Bancroft JD, Gamble A. Theory and practice of histological techniques. 6th ed. New York: Churchill Livingstone; 2008.

Batista FA, Pizzigatti D, Martins CF, Nunes MM, Megda TT, Ribeiro OC, et al. First report of coenurosis in sheep in the State of Mato Grosso do Sul, Brazil. Rev Bras Parasitol Vet 2010; 19(4): 265-267. PMid:21184708. http://dx.doi.org/10.1590/S1984-29612010000400016

Bussell KM, Kinder AE, Scott PR. Posterior paralysis in a lamb caused by a Coenurus cerebralis cyst in the lumbar spinal cord. Vet Rec 1997; 140(21): 560. PMid:9185315. http://dx.doi.org/10.1136/ vr. 140.21 .560

Buxton D. Protozoan infections (Toxoplasma gondii, Neospora caninum and Sarcocystis spp.) in sheep and goats: recent advances. Vet Res 1998; 29(3-4): 289-310. PMid:9689743.

Christodoulopoulos G. Two rare clinical manifestations of coenurosis in sheep. Vet Parasitol 2007; 143(3-4): 368-370. PMid:17027156. http:// dx.doi.org/10.1016/j.vetpar.2006.09.010

Desouky EA, Badawy AI, Refaat RA. Survey on coenurosis in sheep and goats in Egypt. Vet Ital 2011; 47(3): 333-340. PMid:21947971.

Dubey JP. Toxoplasmosis in sheep - the last 20 years. Vet Parasitol 2009; 163(1-2): 1-14. PMid:19395175. http://dx.doi. org/10.1016/j.vetpar.2009.02.026

Dubey JP. Toxoplasmosis of Animals and Humans. 2nd ed. Boca Rotan: CRC Press; 2010. 313 p.

Dubey JP, Beattie CP. Toxoplasmosis of animals and man. Boca Rotan: CRC Press; 1988. 220 p.

Edwards GT, Herbert IV. Observations on the course of Taenia multiceps infections in sheep: clinical signs and post-mortem findings. Br Vet J 1982; 138(6): 489-500. PMid:7150943.

Elmore SA, Jones JL, Conrad PA, Patton S, Lindsay DS, Dubey JP. Toxoplasma gondii: epidemiology, feline clinical aspects, and prevention. Trends Parasitol 2010; 26(4): 190-196. PMid:20202907. http://dx.doi. org/10.1016/j.pt.2010.01.009

Escajadillo A, Frenkel JK. Experimental toxoplasmosis and vaccine tests in Aotus monkeys. Am J Trop Med Hyg 1991; 44(4): 382-389. PMid:2042705.

Gicik Y, Kara M, Arslan MO. Prevalence of Coenurus cerebralis in sheep in Kars province, Turkey. Bull Vet Inst Pulawy 2007; 51(3): 379-382.

Güçlü F, Uslu U, Özdemir Ö. Bilateral bone perforation caused by Coenurus cerebralis in a sheep: case report. Turkiye Parazitol Derg 2006; 30(4): 282-284. PMid:17309028.

Gül Y, İssi M, Özer S. Clinical and pathological observations of flock of sheep showing epileptoid spasm related to Oestrosis and Coenurosis. $F$ Ü Să̆lık Bil Derg 2007; 21(4): 173-177.

Herbert LV, Edwards GT, Willis JM. Some host factors which influence the epidemiology of Taenia multiceps infections in sheep. Ann Trop Med Parasitol 1984; 78(3): 243-248. PMid:6486930. 
Innes EA, Bartley PM, Buxton D, Katzer F. Ovine toxoplasmosis. Parasitology 2009; 136(14): 1887-1894. PMid:19995468. http://dx.doi. org/10.1017/S0031182009991636

Kijlstra A, Jongert E. Control of the risk of human toxoplasmosis transmitted by meat. Int J Parasitol 2008; 38(12): 1359-1370. PMid:18694755. http://dx.doi.org/10.1016/j.ijpara.2008.06.002

Leontides S, Psychas V, Argyroudis S, Giannati-Stefanou A, PaschaleriPapadopoulou E, Manousis T, et al. A survey of more than 11 years of neurologic diseases of ruminants with special reference to transmissible spongiform encephalopathies (TSEs) in Greece. J Vet Med B 2000; 47(4): 303-309. http://dx.doi.org/10.1046/j.14390450.2000.00348.x

Manunta ML, Evangelisti MA, Burrai GP, Columbano N, Ligios C, Varcasia A, et al. Magnetic resonance imaging of the brain and skull of sheep with cerebral coenurosis. Am J Vet Res 2012; 73(12):1913-1918. PMid:23176417. http://dx.doi.org/10.2460/ajvr.73.12.1913

Nayel M, El-Dakhly Kh M, Aboulaila M, Elsify A, Hassan H, Ibrahim $\mathrm{E}$, et al. The use of different diagnostic tools for Babesia and Theileria parasites in cattle in Menofia, Egypt. Parasitol Res 2012; 111(3): 10191024. PMid:22543747. http://dx.doi.org/10.1007/s00436-012-2926-6

Nourani H, Kheirabadi KP. Cerebral coenurosis in a goat: pathological findings and literature review. Comp Clin Pathol 2009; 18(1):85-87. http://dx.doi.org/10.1007/s00580-008-0742-2

Oge H, Oge S, Gonenc B, Ozbakis G, Asti C. Coenurosis in the lumbar region of a goat: a case report. Vet Med-Czech 2012; 57(6); 308-313.

Ozkan C, Yildrin S, Kaya A. Clinical coenurosis (Coenurus cerebralis) and associated pathological findings in a calf. Pak Vet J2011;31(3): 263-266.

Paltrinieri S, Varcasia A, Cazzaniga S, Giordano A, Pipia AP, Marrosu $\mathrm{R}$, et al. Brain creatine kinase isoenzyme (CK-BB) as a possible biomarker for the diagnosis in vivo of ovine coenurosis in a naturally infected flock. Small Ruminant Res 2010; 94(1-3): 180-184. http://dx.doi. org/10.1016/j.smallrumres.2010.07.010

Rissi DR, Rech RR, Pierezan F, Gabriel AL, Trost ME, Barros CSL. Coenurosis in sheep in Southern Brazil: 16 cases. Cienc Rural 2008; 38(4): 1044-1049. http://dx.doi.org/10.1590/S010384782008000400021
Scala A, Cancedda GM, Varcasia A, Ligios C, Garippa G, Genchi C. A survey of Taenia multiceps coenurosis in Sardinian sheep. Vet Parasitol 2007; 143(3-4): 294-298. PMid:16973285. http://dx.doi. org/10.1016/j.vetpar.2006.08.020

Schuster RK, Sivakumar S, Wieckowsky T. Non-cerebral coenurosis in goats. Parasitol Res 2010; 107(3):721-726. PMid:20502917. http:// dx.doi.org/10.1007/s00436-010-1919-6

Sharma DK, Chauhan PPS. Coenurosis status in Afro-Asian region: A review. Small Ruminant Res 2006; 64(3): 197-202. http://dx.doi. org/10.1016/j.smallrumres.2005.05.021

Summers BA, Cummings JF, Lahunta A. Veterinary Neuropathology. St. Louis: Mosby-Year Book; 1995.

Tavassoli M, Malekifard F, Soleimanzadeh A, Tajik H. Prevalence of Coenurus cerebralis in sheep in Northwest of Iran. Vet Res Forum 2011; 2(4): 274-276.

Tenter AM. Toxoplasma gondii in animals used for human consumption. Mem Inst Oswaldo Cruz 2009; 104(2): 364-369. PMid:19430665. http:// dx.doi.org/10.1590/S0074-02762009000200033

Tzanidakis N, Maksimov P, Conraths FJ, Kiossis E, Brozos C, Sotiraki S, et al. Toxoplasma gondii in sheep and goats: Seroprevalence and potential risk factors under dairy husbandry practices. Vet Parasitol 2012; 190(3-4): 340-348. PMid:22883972. http://dx.doi. org/10.1016/j.vetpar.2012.07.020

Uslu U, Güçlü F. Prevalence of Coenurus cerebralis in sheep in Turkey. Med Weter 2007; 63(6): 678-680.

Varcasia A, Tosciri G, Coccone GNS, Pipia AP, Garippa G, Scala A, et al. Preliminary field trial of a vaccine against coenurosis caused by Taenia multiceps. Vet Parasitol 2009; 162(3-4): 285-289. PMid:19345506. http://dx.doi.org/10.1016/j.vetpar.2009.03.008

Veronesi F, Lepri E, Marchesi MC, Fillippini G, Mandara MT. A focus of brain coenurosis in sheep from an Umbrian stock farm. Large Anim Rev 2008; 14(5): 217-222.

Welchman DB, Bekr-Ochir G. Spinal coenurosis causing posterior paralysis in a goat in Mongolia. Vet Rec 2006; 158(7): 238-239. http:// dx.doi.org/10.1136/vr.158.7.238 